\title{
Impact of Innovation on Economic Growth: Evidence from Malaysia
}

\author{
Siong Hook Law ${ }^{a}$ \\ Universiti Putra Malaysia \\ Tamat Sarmidi ${ }^{b}$ \\ Universiti Kebangsaan Malaysia \\ Lim Thye Goh ${ }^{c}$ \\ University of Malaya
}

\begin{abstract}
This study empirically investigates the effect of innovation on economic growth using the neoclassical economic growth model. Embarking from the traditional labour growth, physical capital and human capital framework, innovation is postulated to be the main driver for robust economic growth. Using time series techniques, we discover very attention-grabbing findings that highlight the impact of innovation on economic growth for Malaysia. First, the innovation measured by the quantity of a total number of a patent application is statistically insignificant. The result is robust for various innovation measurements, including total local patent application and total foreign patent application. Interestingly, switching to total patent grant instead of a total number of patent application (local or foreign), the empirical result shows a significant impact on economic growth. The finding indirectly reveals the crucial impact of quality innovation rather than the quantity concern. Neglecting both quality and the commercialisation process of these new technologies may not solve the rigidity of knowledgecommercialisation paradox. Finally, we test for the prominent institutional quality in mediating economic growth under a knowledge-based economy. The interaction between institutional quality and the total patent grant has significantly accelerated the role of innovation channel to economic growth. The empirical findings imply that inadequacy of innovative technology flow over the long term has a detrimental effect on national innovative capacity. Thus, the innovation-economic growth nexus needs to be complemented with a good institutional quality framework, skilled human capital and broader networking to commercialise the innovative product to ensure that the innovation activities promote economic growth.
\end{abstract}

Keywords: ARDL, economic growth, innovation, institutions, quality innovation JEL classification: 011, 031, 043

a Department of Economics, School of Business and Economics, Universiti Putra Malaysia, 43400 UPM Serdang, Selangor, Malaysia. Email: lawsh@upm.edu.my (Corresponding author)

b School of Economics, Faculty of Economics and Management, Universiti Kebangsaan Malaysia, 43600 UKM, Bangi Selangor, Malaysia. Email: tamat@ukm.edu.my

c Department of Economics, Faculty of Economics and Adminstration, University of Malaya, 50603 Kuala Lumpur, Malaysia. Email: Itgoh@um.edu.my

* Acknowledgement: We are grateful for the financial support from the Fundamental Research Grant Scheme (FRGS), Ministry of Higher Education, Malaysia (Grant No. 5524598, UPM), and useful comments from the participants of Malaysian Institute of Economic Research (MIER) National Economic Outlook Conference, Kuala Lumpur, 27-28 November 2018.

Article Info: Received 11 August 2019; Revised 6 April 2020; Accepted 20 April 2020

https://doi.org/10.22452/MJES.vol57no1.6 


\section{Introduction}

Sustainable economic growth issue has been a central discussion in the economic development debate. Apart from proposing growth determinants, finding a new feasible growth driver is of utmost importance. Some economists have argued that policies, which embrace openness, competition and productivity improvement, will promote sustainable growth. Others have countered that the strategy should emphasise domestic innovation activity - and preferably high-tech manufacturing. Malaysia, as an emerging economy, also redefines its growth strategy via the New Economic Model (NEM) in 2010 and the Economic Transformation Program by identifying the main key areas to stimulate economic growth. Nevertheless, the question of maintaining high economic growth has been a continuous academic discourse significant subject of ongoing debate. ${ }^{1}$

Recent economic growth theories postulate that a new range of innovative products or business model as an outcome of continuous research and innovation is another primary catalyst of productivity and economic growth. Any move towards promoting innovation should be a priority. Figure 1 depicts that the innovation activities of upper-middle-income countries are catching up with the high-income countries

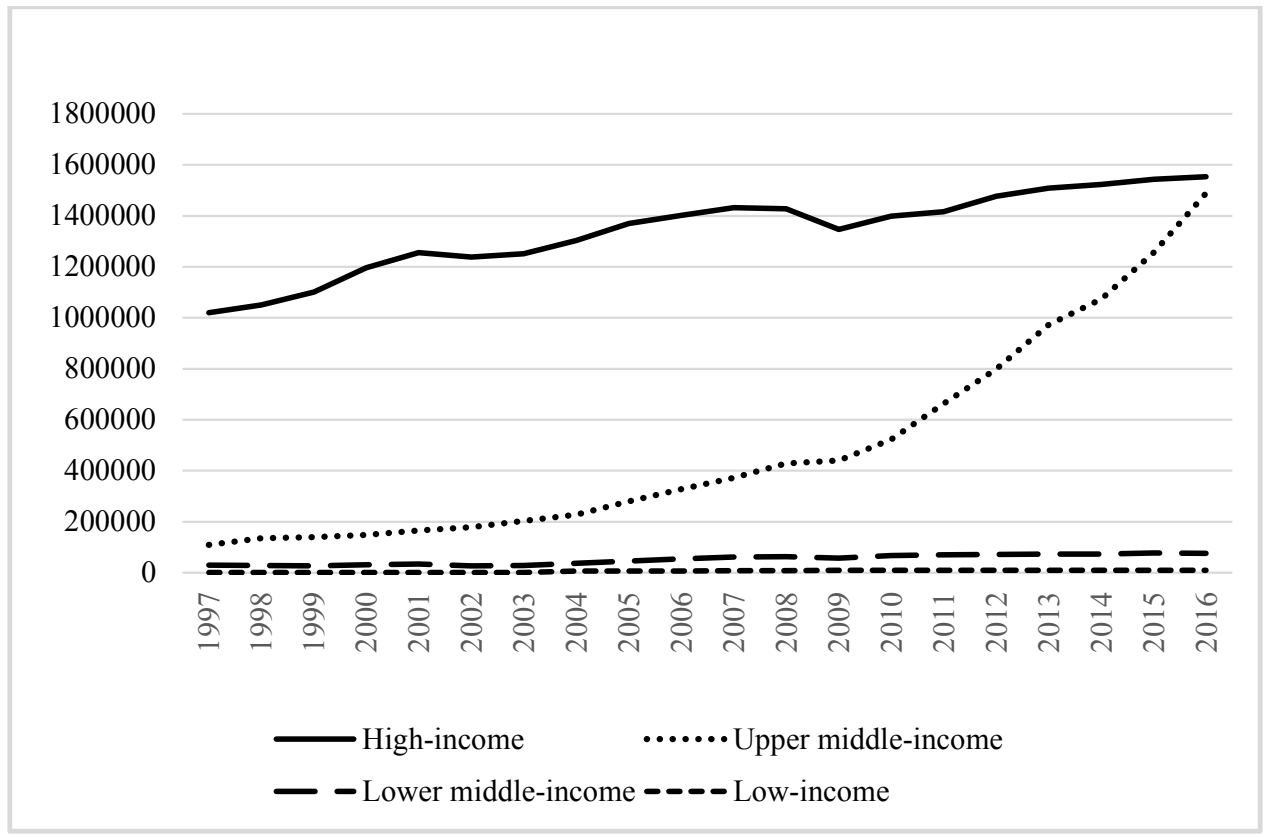

Figure 1. Innovations (total patent application) at different income levels

1 The goal of the NEM is to "transform the Malaysian economy to become one with high incomes and quality growth" by 2020. At the time of the plan's unveiling in 2010, per capita annual income in Malaysia stood at US\$7,000, under the plan that figure would more than double to US\$15,000. The keys to the plan are "high income, sustainability and inclusiveness". 
where these two income levels converge to a similar point. In terms of Malaysian innovation performance compared to the world, Malaysia was ranked 35th in 2018 and 37th in 2017 by the World Economic Forum (WEF) based on the Global Innovation Index (GII). The indicator suggests that Malaysia's innovation has improved comparatively among its peers, but to be in the select group of high-income countries, improvement of innovation will be necessary and the way to move forward.

The dynamic relationship between innovation and economic growth can be traced back to Schumpeter (1939), who argued that competition through innovation and education are important in ensuring economic growth; and these assumptions are supported by empirical studies (Aghion, Bloom, Blundell, Griffith, \& Howitt, 2005). According to Schumpeter, innovation which manifest itself in the shape of investment is a driver of economic development. Investment, in turn, is driven by profit expectations. Thus, if a country wants to promote economic growth, then a country should find a way to turn on profit expectations of investment. Another strand of theoretical discussion is the endogenous growth model developed by Romer (1986), where the economic growth is endogenously determined and is influenced by agents' decisions to maximise profits, taking into consideration aspects related to entrepreneurship by modelling the innovation process. In the endogenous growth literature, many models (Grossman \& Helpman, 1991; Romer, 1990) illustrate the function of innovation as a growth engine, and government plays an important role in achieving an optimum level of innovation and R\&D. The distinction between Schumpeterian models (Aghion \& Howitt, 1992) and Romerian models rest on how they interpret innovation and what drives innovation (quality ladder vs product variety expansion).

This paper examines the effect of innovation on economic growth in Malaysia using time series analysis. According to Mc Morrow and Röger (2009), an economy's agility to develop cutting edge technologies and adapt to a fast changing technological environment is crucial to its prospects of improving people's welfare and creating economic prosperity. This study contributes to the literature in three important aspects. First, we utilise the total patent applications and total patent grants as innovation measurements which are both widely used in the literature. However, in this study, we postulate that the innovation measured by the quantity of total number of patent application is not a good choice for innovation proxy. Therefore, this study uses total patent granted which indirectly reveals the crucial impact of the quality innovation instead of total number of patent application which is more of quantity measurement, has shown robust significant impact on economic growth. Second, the autoregressive distributed lag (ARDL) model is applied to evaluate the effect of innovation on economic growth. The ARDL bounds testing methodology develop by Pesaran, Shin and Smith (2001) has few advantages over other cointegration testing. Apart from its effiency to handle the small sample size, the ARDL could estimate a mixture of order of integration, i.e. integration of level $[I(0)]$ and first difference [I(1)]. The estimation uses a singleequation set-up which makes the estimation procedure less complicated. Another advantage is that the interpretation of each variable can be dedicated to different laglengths as they enter the model. Third, this study not only uses a linear ARDL model, but it also uses the quantile regression to observe information on the asymmetric and 
non-monotonic effects of the conditional variables on the dependent variable. It can capture the impact of rapid changes in innovation on the direction and magnitude of economic performance across different quantiles. Fourth, this study also compares the relative importance of foreign and local innovations in influencing economic growth. Last, this study also examines the role of institutional quality in mediating the effect of innovation-economic growth nexus.

The organisation of the study is as follows. Section 2 delves into the literature. Section 3 lays out the econometric estimation technique and the data sources. Section 4 focuses on the empirical results. Finally, Section 5 concludes.

\section{Literature Review}

A well-documented literature among development economists suggests that innovation is the seed of productivity growth, hence, resulting in translating high level of innovation engagement to sustainable real GDP growth (Gill \& Kharas, 2007; Pece, Simona, \& Salisteanu, 2015; Pradhan, Arvin, \& Bahmani, 2018). The vital role of innovation as a growth engine and the importance of achieving an optimum level of innovation and R\&D to economic growth has its origin from Schumpeter (1939), Romer (1986 and 1990), Grossman and Helpman (1991) and empirically supported by Aghion et al. (2005).

Using recent data, Lee and Kim (2009) revisited the debate and empirically found that factors such as technology, tertiary education and institutions are a significant determinant to economic growth. Interestingly, technology and higher education have been conclusively affecting economic growth for the upper-middle-income and highincome countries, but not for the lower-middle- and low-income countries. On the same account, an economy characterised with good quality education at both secondary and tertiary level and have a high-tech product share in export goods demonstrate resilience in economic growth to any slowdown effect (Eichengreen, Park, \& Shin, 2013). This finding highlights the importance of moving up the technology ladder and indicates that innovation-enhancing growth strategies should receive priority.

Innovation management system and market protection for new ideas are other aspects to be considered to enhance further the role of innovation to economic growth. In this regard, Jalles (2010) found that countries with a higher degree of intellectual property rights (IPR), which reflects market protection for new ideas, generally have a higher level of income per capita. Wu, Zhuo and Wu (2017) found that the national innovation system (NIS) has significantly promoted social entrepreneurial action and enhanced economic growth in China's rural sectors. Hasan and Tucci (2010), on the other hand, stressed the importance of both the quantity (measured by total R\&D expenditure) and quality of innovation (the ratio of patents granted in the United States as a proportion of total patents granted by the country) to economic growth. The study which analyses a sample of 58 countries covering 1980-2003 found that both the quantity and quality of inventive activities are associated with economic growth. The findings also demonstrate that those countries that have a high level of patenting, experience a concerted increase in economic growth. 
With respect to the causality effect between innovation and economic growth, Galindo and Méndez (2014) analysed the feedback effects of a dynamic relationship among entrepreneurship, innovation and economic growth. They use entrepreneurial activity in 13 developed countries as a sample and the time period is from 2002 to 2007. Their empirical results based on panel data with fixed effects show that several factors, including monetary policy and social climate, have positive impacts on innovation and entrepreneurship. Furthermore, a bi-directional feedback effect is found from economic activity to entrepreneurship and innovation activities. This implies that there is a bi-directional feedback effect between innovation and economic activity.

In the case of high-income OECD countries, Guloglu and Tekin (2012) examined the causal relations among research and development (R\&D) expenditures, innovation and economic growth using the panel vector autoregressive (VAR) model under the GMM and panel fixed effects framework. The study supports the endogenous growth theory where there is evidence of Granger causality from R\&D expenditures to innovation, and technological innovations to economic growth. Interestingly, there is no evidence of reverse causality from economic growth to innovation; i.e. the rate of output growth Granger cause the technological change. The multivariate causality tests further confirm that both the market size and rate of innovation Granger cause R\&D activity; while an increase in national output and R\&D intensity jointly Granger-cause technological change. These empirical results depict that both the "technology-push" and "demandpull" models of innovation are equally viable.

With regard to the roles of domestic innovation and foreign innovation in enhancing economic growth, Yang (2006) found that both domestic patenting and world discoveries of ideas are significantly driving the economic growth in Taiwan. The finding confirms that both domestic innovation and foreign innovation activities are equally important in promoting economic growth. Schneider (2005), on the other hand, found that foreign technology has a more substantial impact on per capita gross domestic product (GDP) growth than domestic technology. The empirical analysis is conducted using a panel dataset of 47 developed and developing countries. He argued that the roles of domestic innovation and foreign innovation are country-specific, where a time series analysis is more relevant in addressing this issue than a panel data analysis. Nevertheless, Cameron (1998) pointed out that positive technology spillovers tend to benefit multinational firms more while limiting local firms. The study suggests that although technological advancement across countries is converging to world productivity, the cathing up process is supposed to be slow, uncertain and require substantial domestic innovative effort.

Using 61 countries over the sample period from 2000 to 2011, Tan and Azman-Saini (2017) analysed the role of product market competition in accelerating the positive impact of foreign direct investment (FDI) on domestic research and development (R\&D). The empirical results based on the panel generalized method of moments (GMM) demonstrate that FDI has a little direct effect on R\&D expenditure. In other words, competition has a relatively moderate positive impact of FDI on domestic innovation. The finding is inconsistent with conventional wisdom regarding the merits of competition as evidence shows that competition undermines the effect of FDI on domestic innovation activities. 
In short, innovation level is a critical determinant of economic growth. ${ }^{2}$ Recently, the importance of innovation has been reinforced by both globalisation and advancement in information and communication technology which opened up new forms of competition and markets creation for innovative products and services. Nevertheless, a much more systematic approach that analyses the competition-growth nexus is still limited in the case of Malaysia. This study takes the first step in this direction.

\section{Empirical Model, Methodology and the Data}

To test the effect of innovation on economic growth, this study utilises the frameworks suggested by Mankiw, Romer and Weil (1992), Knight, Loayza and Villaneura (1993) and Law and Azman-Saini (2013). They applied the following Cobb-Douglas production function:

$$
Y_{t}=K_{t}^{\alpha} H_{t}^{\beta}\left(P_{t} L_{t}\right)^{1-\alpha-\beta}
$$

where $\mathrm{Y}$ is real GDP per capita, $\mathrm{K}$ is physical capital stock, $\mathrm{H}$ is human capital, $\mathrm{L}$ is labour, $P$ is a labour-augmenting factor replicating the technological progress (innovation) and institutions effectiveness (institutional quality) in the economy and subscript $t$ indicates time. Let's say $\alpha+\beta<1$, this indicates that there are diminishing returns for all capital. Labour and labour-augmenting factor are assumed to progress based on the following functions:

$$
\begin{aligned}
& \mathrm{L}_{\mathrm{t}}=\mathrm{L}_{0} \mathrm{e}^{n t} \\
& \mathrm{P}_{\mathrm{t}}=\mathrm{P}_{0} \mathrm{e}^{g t+V \phi}
\end{aligned}
$$

where $n$ is exogenous rate of growth of the labour force, $g$ is exogenous rate of technological progress, $V$ is a vector of institutions and government policies that could move the technology and efficiency levels in the economy, and $\phi$ is a vector of coefficients associated with these institutions and government policies variables.

In this context, the state of labour-augmenting technology (variable $\mathrm{P}$ ) is subject to exogenous technological change, determined by $g$ and on a country's institutions and policy position namely corruption, law and order, bureaucratic quality, government stability, transparency and accountability. The technological change is stimulated by innovation such as on number of patents, number of grants, R\&D, economic complexity and trade mark; and these innovations have a propensity for increasing the productive sector's efficiency or increasing the productivity of investment. In the steady state, output per active worker (Y/PL) is constant while output per worker (Y/L) rises at the exogenous rate $g$ (the exogenous element of the growth rate of the efficiency variable $\mathrm{P})$.

In reduced form, the output per worker can be reorganised as follows:

$$
\mathrm{RGDPC}_{\mathrm{t}}=\beta_{0}+\beta_{1} \mathrm{INNO}_{\mathrm{t}}+\beta_{2} \mathrm{INS}_{\mathrm{t}}+\beta_{3} \mathrm{~K}_{\mathrm{t}}+\beta_{4} \mathrm{HC}_{\mathrm{t}}+\beta_{5} \mathrm{PG}_{\mathrm{t}}+\varepsilon_{\mathrm{t}}
$$

\footnotetext{
2 Aghion et al. (2005) investigated the relationship between product market competition and innovation. Using panel data, they found strong evidence of an inverted-U relationship between these variables.
} 
To evaluate the role of institutions in innovation, this study includes the interaction term between innovation and institutions as follows:

$$
\mathrm{RGDPC}_{\mathrm{t}}=\beta_{0}+\beta_{1} \mathrm{INNO}_{\mathrm{t}}+\beta_{2} \mathrm{INS}_{\mathrm{t}}+\beta_{3}\left(\mathrm{INNO}_{\mathrm{t}} \times \mathrm{INS}_{\mathrm{t}}\right)+\beta_{4} \mathrm{~K}_{\mathrm{t}}+\beta_{5} \mathrm{HC}_{\mathrm{t}}+\beta_{6} \mathrm{PG}_{\mathrm{t}}+\varepsilon_{\mathrm{t}}
$$

where $\beta$ is the parameter to be estimated, RGDPC is real GDP per capita, INNO is innovation, INS is institutions, $\mathrm{K}$ is physical capital, $\mathrm{HC}$ is human capital, $\mathrm{PG}$ is population growth, and $\varepsilon_{t}$ is an error term. If $\beta_{1}$ is positive and significant, this demonstrates that innovation is an important determinant factor of economic performance. The remaining parameters namely $\beta_{2}, \beta_{3}, \beta_{4}$ and $\beta_{5}$ are also expected to be positive, which include the interaction term, institutions, physical capital and human capital, whereas the parameter of population growth $\left(\beta_{6}\right)$ is projected to be negative.

\subsection{Econometric Estimation Methods}

i) ARDL Linear Bounds Test and Level Relations

The autoregressive distributed lagged (ARDL) model assumes that the linear bounds test leads to the conclusion of long-run cointegration and there is no non-linear relationship. Thus, we can expressively estimate the long-run level relationship between the variables based on Pesaran et al. (2001) uniform lag length ( $p, p, p, p, p, p)$ as follows:

$$
\begin{aligned}
\operatorname{RGDPC}_{\mathrm{t}}= & \beta_{0}+\sum_{\mathrm{i}=1}^{\mathrm{p}} \beta_{\mathrm{i}} \operatorname{RGDPC}_{\mathrm{t}-\mathrm{i}}+\sum_{\mathrm{j}=0}^{\mathrm{p}} \gamma_{\mathrm{j}} \Delta \mathrm{INNO}_{\mathrm{t}-\mathrm{j}}+\sum_{\mathrm{k}=0}^{\mathrm{p}} \delta_{\mathrm{k}} \Delta \mathrm{INS}_{\mathrm{t}-\mathrm{k}}+\sum_{\mathrm{l}=0}^{\mathrm{p}} \lambda_{\mathrm{I}} \Delta \mathrm{K}_{\mathrm{t}-\mathrm{l}}+ \\
& \sum_{\mathrm{m}=0}^{\mathrm{p}} \varphi_{\mathrm{m}} \Delta \mathrm{HC} \mathrm{C}_{\mathrm{t}-\mathrm{m}}+\sum_{\mathrm{n}=0}^{\mathrm{p}} \eta_{\mathrm{n}} \Delta \mathrm{PG}_{\mathrm{t}-\mathrm{n}}+\theta_{0} \mathrm{RGDPC}_{\mathrm{t}-1}+\theta_{1} \mathrm{INNO}_{\mathrm{t}-1}+\theta_{2} \mathrm{INS}_{\mathrm{t}-1}+ \\
& \theta_{3} \mathrm{~K}_{\mathrm{t}-1}+\theta_{4} \mathrm{HC}_{\mathrm{t}-1}+\theta_{5} \mathrm{PG}_{\mathrm{t}-1}+\mathrm{e}_{\mathrm{t}}
\end{aligned}
$$

The same lag length is contingent on serial correlation or autocorrelation test (if there is a serial correlation problem, then the general to specific (GTS) procedure is employed to obtain different lag length $(p, q, r, s, t, u)$. For example, if $\operatorname{ARDL}(1,1,1,1,1,1)$ is the optimal lagged model, then Equation (6) is as follows:

$$
\begin{aligned}
\text { RGDPC }_{\mathrm{t}}= & \mu_{\mathrm{i}}+\beta \mathrm{RGDPC}_{\mathrm{t}-1}+\delta_{1} \mathrm{INNO}_{\mathrm{t}}+\delta_{2} \mathrm{INNO}_{\mathrm{t}-1}+\delta_{3} \mathrm{INS}_{\mathrm{t}}+\delta_{4} \mathrm{INS}_{\mathrm{t}-1}+ \\
& \delta_{5} \mathrm{~K}_{\mathrm{t}}+\delta_{5} \mathrm{~K}_{\mathrm{t}-1}+\delta_{6} \mathrm{HC}_{\mathrm{t}}+\delta_{7} \mathrm{HC}_{\mathrm{t}-1}+\delta_{8} \mathrm{PG}_{\mathrm{t}}+\delta_{9} \mathrm{PG}_{\mathrm{t}-1}+\varepsilon_{\mathrm{t}}
\end{aligned}
$$

and the short-run error-correction model (ECM) equation is represented as follows:

$$
\begin{aligned}
\Delta \mathrm{RGDPC}_{\mathrm{t}}= & \beta_{0}+\sum_{\mathrm{i}=1}^{p} \beta_{\mathrm{i}} \Delta R \mathrm{RDPC}_{\mathrm{t}-\mathrm{i}}+\sum_{\mathrm{j}=0}^{q} \gamma_{\mathrm{j}} \Delta \mathrm{INNO}_{\mathrm{t}-\mathrm{j}}+\sum_{\mathrm{k}=0}^{r} \delta_{\mathrm{k}} \Delta \mathrm{INS}_{\mathrm{t}-\mathrm{k}}+\sum_{\mathrm{m}=0}^{s} \eta_{\mathrm{m}} \Delta \mathrm{K}_{\mathrm{t}-\mathrm{m}}+ \\
& \sum_{\mathrm{n}=0}^{v} \theta_{\mathrm{n}} \Delta \mathrm{HC} C_{\mathrm{t}-\mathrm{n}}+\sum_{\mathrm{o}=1}^{w} \tau_{\mathrm{o}} \Delta \mathrm{PG}_{\mathrm{t}-\mathrm{o}}+\phi \mathrm{Z}_{\mathrm{t}-1}+\mathrm{e}_{\mathrm{t}}
\end{aligned}
$$


where $z_{\mathrm{t}-1}=\left(\mathrm{RGDPC}_{\mathrm{t}-1}-\alpha_{0}-\alpha_{1} \mathrm{INNO}_{\mathrm{t}-1}-\alpha_{2} \mathrm{INS}_{\mathrm{t}-1}-\alpha_{3} \mathrm{~K}_{\mathrm{t}-1}-\alpha_{4} \mathrm{HC}_{\mathrm{t}-1}-\alpha_{5} \mathrm{PG}_{\mathrm{t}-1}\right)$ or the error correction term (ECT) and the $\alpha s$ are the ordinary least squares (OLS) estimates of the $\alpha s$ in Equation (8). The $\phi$ in Equation (8) is the short-run equation that contains the ECT that evaluates the quickness of adjustment of the short-run deviation to longrun equilibrium. $p, q, r, s, v$ and $w$ are the optimal lagged lengths, selected using the Schwarz Bayesian criterion (SBC).

Based on the above $\operatorname{ARDL}(1,1,1,1,1,1)$ model, we can compute the long-run coefficients of the determinants: ${ }^{3}$

$$
\varphi_{I N N O}=\frac{\gamma_{1}+\gamma_{2}}{1-\beta_{i}} ; \varphi_{I N S}=\frac{\delta_{1}+\delta_{2}}{1-\beta_{i}} ; \varphi_{K}=\frac{\eta_{1}+\eta_{2}}{1-\beta_{i}} ; \varphi_{H C}=\frac{\theta_{1}+\theta_{2}}{1-\beta_{i}} ; \varphi_{P G}=\frac{\tau_{1}+\tau_{2}}{1-\beta_{i}} ;
$$

After getting the long-run equation, the error terms of the equation will be the errorcorrection term. The dependent variable for the short-run is changes $(\Delta)$ of RGDPC, and all the independent variables as well as in all changes. The short-run equation can be formulated as follows:

$$
\begin{aligned}
\Delta \mathrm{RGDPC}_{\mathrm{t}}= & \alpha+\sum_{\mathrm{i}=1}^{p-1} \alpha_{\mathrm{i}} \Delta \mathrm{RGDPC}_{\mathrm{t}}+\sum_{\mathrm{j}=0}^{q-1} \alpha_{\mathrm{j}} \Delta \mathrm{INNO}_{\mathrm{t}}+\sum_{\mathrm{k}=0}^{r-1} \alpha_{\mathrm{k}} \Delta \mathrm{INS}_{\mathrm{t}}+\sum_{\mathrm{m}=0}^{s-1} \alpha_{\mathrm{m}} \Delta \mathrm{K}_{\mathrm{t}}+ \\
& \sum_{\mathrm{n}=0}^{v-1} \alpha_{\mathrm{n}} \Delta \mathrm{HC}_{\mathrm{t}}+\sum_{\mathrm{o}=1}^{w-1} \alpha_{\mathrm{o}} \Delta \mathrm{PG}_{\mathrm{t}}+\mathrm{ECT}_{\mathrm{t}-1}+\mathrm{e}_{\mathrm{t}}
\end{aligned}
$$

\section{ii) Quantile Regression}

To evaluate for the nonlinearity in the relationship between the impact of innovation on economic performance, this study also uses a quantile regression to identify the effects under two dissimilar innovation indicators (Koenker, 2005; Koenker \& Bassett, 1978). The purpose for selecting the nonlinear approach can be clarified by the spread of the innovation which is possible to capture using numerous quantiles. A quantile regression can disclose evidence on the unequal and non-linear results of the conditional variables on the dependent variable. In addition, it can detect the outcome of unforeseen changes in innovation on the signal and strength of economic performance across different quantiles. The regular linear regression procedures recap the average association between a set of independent variables $(x)$ and the dependent variable $(y)$ using the conditional mean function $E(y \mid x)$. This offers merely a partial interpretation of the association, as this study analyses the association at dissimilar points in the conditional spreading of real GDP per capita, the quantile regression provides such capability in investigating the association between innovation and economic performance.

3 The long-run coefficients depend on the lag structure of the ARDL model; thus, different lags will yield different model specifications and derive different long-run elasticity equations. 


\subsection{Data}

This study utilises yearly time series data spanning from 1985 to 2016 with 32 observations. ${ }^{4}$ The sources of the data are from the World Development Indicators (WDI) and World Intellectual Property Organization (WIPO). The real gross domestic product (RGDP) per capita is obtained from the WDI in terms of US\$ constant prices. Total patent applications and total number of grants are used as a measure of innovation following previous literature and these datasets are obtained from WIPO.

The physical capital stock is measured by using gross investment values based on the perpetual inventory method. Initial physical capital stocks are computed using the assumption that over long periods of time physical capital and output grow at the same rate. Following Hall and Jones (1999), a depreciation rate of $6 \%$ and the mean of economic growth rate of the initial 5 years are used to create the initial level of physical capital stock. Total population is used to measure the labour growth rate and human capital is proxied by life expectancy.

In this study, the institutions (INS) datasets utilised are from the International Country Risk Guide (ICRG) - which is a monthly publication of Political Risk Services (PRS). Based on Knack and Keefer's (1995) study, five PRS indicators are used to compute the institutions, specifically: (i) corruption, (ii) law and order, (iii) government stability, (iv) bureaucratic quality, and (v) democracy and accountability. The first three sub-institutions variables are scaled from 0 to 6 , whereas the last two variables are scaled from 0 to 4 and 0 to 12 , respectively. These five institutions variables are rescaled from 0 to 10 , where higher values indicate better institutions and vice versa. The aggregate institutions variable is obtained by summing the five sub-indicators above, which shows that the scale ranges from 0 to 50 . Several studies have used this dataset in their work, among others, Bekaert, Harvey and Lundblad (2005, 2006), Chong and Calderón (2000), Demetriades and Law (2006), and Law and Azman-Saini (2012).

Tables 1 and 2 show the descriptive statistics and correlations of the variables. As shown in Table 2, the correlation demonstrates that real GDP per capita has a positive relationship with total patent application, total patent grants and institutions. Figure 2 presents the time series plots of the datasets used in the empirical analysis.

Table 1. Descriptive statistics

\begin{tabular}{llrrrr}
\hline & \multicolumn{1}{c}{ Unit of measurement } & Mean & Std dev & Min & Max \\
\hline Real GDP per capita & Ringgit constant 2010 prices & 7101.86 & 1998.88 & 3708.19 & 11031.82 \\
Total patent application & \% of 100000 labour force & 4735.31 & 2011.52 & 262 & 7727 \\
Total grants & \% of 100000 labour force & 2112.82 & 1646.06 & 132 & 6983 \\
Population growth & Percent & 2.86 & 0.36 & 1.70 & 3.54 \\
Human capital & Number of years & 72.64 & 1.60 & 69.48 & 75.30 \\
Physical capital & \% of GDP & 27.96 & 7.42 & 20.57 & 43.58 \\
Institutions & Scaled 0 -50 & 29.95 & 2.91 & 25.14 & 36.32 \\
\hline
\end{tabular}

4 The sample period stops at 2016 due to unavailability of data on institutions, total number of a patent application and total patent granted in the data sources. 
Table 2. Correlations

\begin{tabular}{|c|c|c|c|c|c|c|c|}
\hline & $\begin{array}{l}\text { Real GDP } \\
\text { per capita }\end{array}$ & $\begin{array}{l}\text { Total patent } \\
\text { application }\end{array}$ & $\begin{array}{l}\text { Total } \\
\text { grants }\end{array}$ & $\begin{array}{c}\text { Population } \\
\text { growth }\end{array}$ & $\begin{array}{l}\text { Human } \\
\text { capital }\end{array}$ & $\begin{array}{c}\text { Physical } \\
\text { capital }\end{array}$ & Institutions \\
\hline \multicolumn{8}{|l|}{ Real GDP } \\
\hline per capita & 1 & & & & & & \\
\hline $\begin{array}{l}\text { Total patent } \\
\text { application }\end{array}$ & 0.8179 & 1 & & & & & \\
\hline Total grants & 0.5981 & 0.1755 & 1 & & & & \\
\hline Population growth & -0.9081 & -0.5929 & 0.1755 & 1 & & & \\
\hline Human capital & 0.9875 & 0.8326 & 0.8326 & -0.8912 & 1 & & \\
\hline Physical capital & -0.4764 & -0.3289 & -0.3289 & 0.4285 & -0.5676 & 1 & \\
\hline Institutions & -0.0951 & -0.0447 & -0.0447 & 0.1158 & -0.1637 & 0.5588 & 1 \\
\hline
\end{tabular}

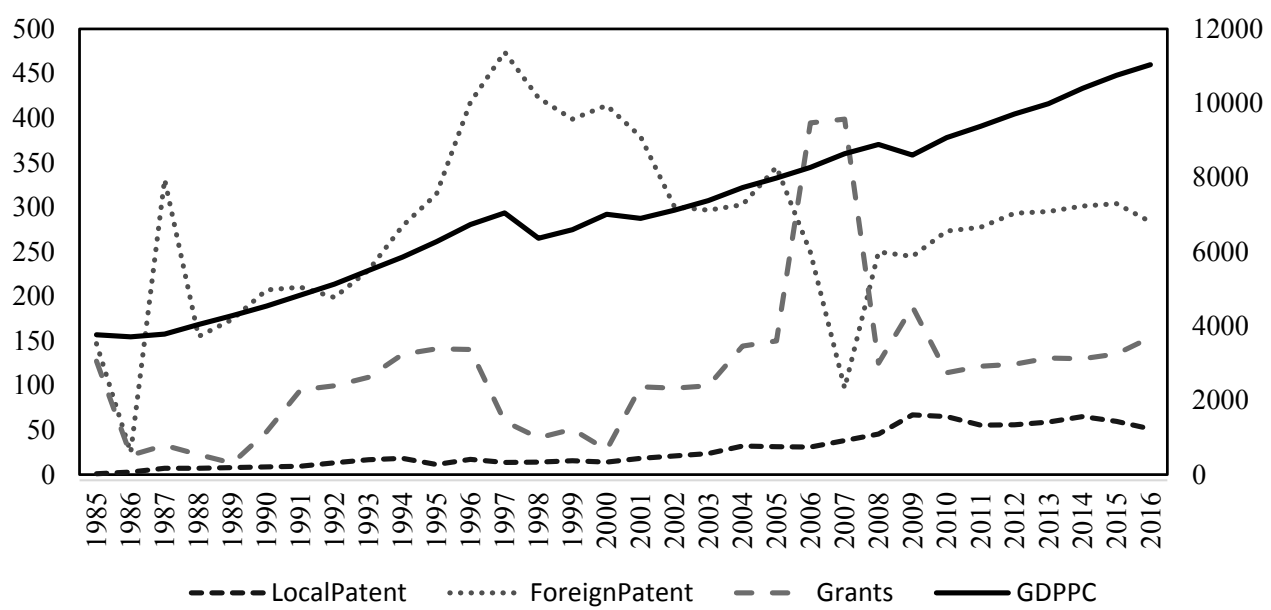

Figure 2. Innovations and real GDP per capita of Malaysia

\section{Empirical Results}

Table 3 presents the unit root tests based on the Augmented Dickey Fuller (ADF) and Philip Perron (PP) tests. The finding demonstrates that all variables are stationary at integrated order one or I(1). The result fulfils the ARDL bounds test criterion of no variable is integrated of order two or I(2).

Table 4 presents the empirical results of the linear ARDL estimation and diagnostic checks using the SBC lagged length selection criterion. The four models have passed the diagnostic checks especially the serial correlation and stability test. The main result is the long-run estimation reported in Table 5, where innovation proxy by total patent application is insignificant, but the total patent grants variable is statistically a significant determinant of economic performance. This finding reveals that quality innovation is 
Table 3. ADF and PP unit root test

\begin{tabular}{|c|c|c|c|c|}
\hline \multirow{2}{*}{ Variable } & \multicolumn{2}{|c|}{ Level } & \multicolumn{2}{|c|}{ First difference } \\
\hline & ADF & PP & ADF & PP \\
\hline Real GDP per capita & -1.1455 & -1.1455 & $-4.9950 * * *$ & $-4.9879 * * *$ \\
\hline Total patent application & -1.7426 & -1.5632 & $-7.1985^{* * *}$ & $-7.9034 * * *$ \\
\hline Total grants & -1.700 & -1.5142 & $-7.268 * * *$ & $-7.3407 * * *$ \\
\hline Population growth & 1.6180 & -1.2475 & $-2.0805^{* *}$ & $-2.0805^{* *}$ \\
\hline Human capital & -1.8500 & $-3.4143^{* *}$ & $-1.6645^{*}$ & $-3.5856 * * *$ \\
\hline Physical capital & -1.4408 & -0.2781 & $-4.2274 * * *$ & $-4.1662 * * *$ \\
\hline Institutions & -1.0021 & -0.9226 & $-3.8662 * * *$ & $-3.6629 * * *$ \\
\hline Foreign innovation & $-3.0869 * *$ & 0.9022 & $-12.3637^{* * *}$ & $-11.4801 * * *$ \\
\hline Local innovation & $-4.2091 * * *$ & 1.6887 & $-5.3267 * * *$ & $-5.8524 * * *$ \\
\hline
\end{tabular}

Notes: The constant and trend terms are included in the test equation and the SIC is utilised for optimal lag order in the ADF test equation. ${ }^{* *}, * *$ and $*$ denotes significance at $1 \%, 5 \%$ and $10 \%$ levels, respectively.

Table 4. Results of ARDL estimation and diagnostic checks

\begin{tabular}{|c|c|c|c|c|}
\hline & \multicolumn{2}{|c|}{$\begin{array}{l}\text { Innovation = Total } \\
\text { patent application }\end{array}$} & \multicolumn{2}{|c|}{ Innovation = Total grants } \\
\hline & Model A & Model B & Model C & Model D \\
\hline \multicolumn{5}{|c|}{ Panel A: Coefficient estimates of linear ARDL } \\
\hline Selected model & $(3,1,0,1,1,1)$ & $(1,0,0,0,0,0,0)$ & $(4,1,0,0,1,0)$ & $(1,1,0,0,0,0,1)$ \\
\hline Constant & $\begin{array}{l}-41.23^{* * *} \\
(10.96)\end{array}$ & $\begin{array}{l}-47.62^{* * *} \\
(9.82)\end{array}$ & $\begin{array}{l}-29.38^{* * *} \\
(8.45)\end{array}$ & $\begin{array}{l}-48.49^{* * *} \\
(7.65)\end{array}$ \\
\hline In Real GDP per capita $\mathrm{t}_{-1}$ & $\begin{array}{l}-0.64 * * * \\
(0.18)\end{array}$ & $\begin{array}{l}-0.79 * * * \\
(0.15)\end{array}$ & $\begin{array}{l}-0.63^{* * *} \\
(0.15)\end{array}$ & $\begin{array}{l}-0.86^{* * *} \\
(0.13)\end{array}$ \\
\hline In Innovation $\mathrm{t}_{\mathrm{t}-1}$ & $\begin{array}{l}-0.06^{* *} \\
(0.02)\end{array}$ & $\begin{array}{l}-0.01 \\
(0.01)\end{array}$ & $\begin{array}{l}0.03^{* *} \\
(0.01)\end{array}$ & $\begin{array}{l}0.02^{* *} \\
(0.01)\end{array}$ \\
\hline In Population growth $\mathrm{t}_{\mathrm{t}-1}$ & $\begin{array}{c}0.10 \\
(0.06)\end{array}$ & $\begin{array}{c}0.06 \\
(0.06)\end{array}$ & $\begin{array}{l}-0.001 \\
(0.05)\end{array}$ & $\begin{array}{c}0.09 * \\
(0.04)\end{array}$ \\
\hline In Human capital $\left.\right|_{t-1}$ & $\begin{array}{l}10.76^{* * *} \\
(2.86)\end{array}$ & $\begin{array}{l}12.55^{* * *} \\
(2.55)\end{array}$ & $\begin{array}{l}7.89 * * * \\
(2.22)\end{array}$ & $\begin{array}{l}12.89 * * * \\
(2.00)\end{array}$ \\
\hline In Physical capital $\mathrm{t}_{\mathrm{t}-1}$ & $\begin{array}{l}0.17^{* * *} \\
(0.04)\end{array}$ & $\begin{array}{l}0.10^{* * *} \\
(0.02)\end{array}$ & $\begin{array}{l}0.10^{* * *} \\
(0.03)\end{array}$ & $\begin{array}{l}0.09 * * * \\
(0.02)\end{array}$ \\
\hline In Institutions $\mathrm{t}_{-1}$ & $\begin{array}{l}0.22^{* * *} \\
(0.08)\end{array}$ & $\begin{array}{c}0.14^{*} \\
(0.08)\end{array}$ & $\begin{array}{l}0.18^{* *} \\
(0.08)\end{array}$ & $\begin{array}{c}0.10 \\
(0.07)\end{array}$ \\
\hline In Innovation $\mathrm{t}_{\mathrm{t}-1} \mathrm{x} \ln$ Institutions $\mathrm{t}_{\mathrm{t}-1}$ & & $\begin{array}{c}0.001^{*} \\
(0.001)\end{array}$ & & $\begin{array}{l}0.002^{* * *} \\
(0.001)\end{array}$ \\
\hline
\end{tabular}


Table 4. Continued

\begin{tabular}{|c|c|c|c|c|}
\hline & \multicolumn{2}{|c|}{$\begin{array}{l}\text { Innovation = Total } \\
\text { patent application }\end{array}$} & \multicolumn{2}{|c|}{ Innovation = Total grants } \\
\hline & Model A & Model B & Model C & Model D \\
\hline$\Delta$ In Real GDP per capita ${ }_{\mathrm{t}-1}$ & $\begin{array}{l}-0.31^{*} \\
(0.15)\end{array}$ & & $\begin{array}{l}-0.33^{* *} \\
(0.14)\end{array}$ & \\
\hline$\Delta$ In Real GDP per capita ${ }_{t-2}$ & $\begin{array}{l}-0.25^{*} \\
(0.13)\end{array}$ & & $\begin{array}{l}-0.32 * * \\
(0.14)\end{array}$ & \\
\hline$\Delta$ In Real GDP per capita ${ }_{t-3}$ & & & $\begin{array}{l}-0.25 \\
(0.14)\end{array}$ & \\
\hline$\Delta \ln$ Innovation $_{\mathrm{t}}$ & $\begin{array}{l}-0.01 * * * \\
(0.02)\end{array}$ & $\begin{array}{l}-0.01 \\
(0.01)\end{array}$ & $\begin{array}{l}-0.001 \\
(0.01)\end{array}$ & $\begin{array}{l}-0.005 \\
(0.007)\end{array}$ \\
\hline$\Delta$ In Population growth ${ }_{\mathrm{t}}$ & $\begin{array}{c}0.10 \\
(0.06)\end{array}$ & $\begin{array}{c}0.06 \\
(0.06)\end{array}$ & $\begin{array}{l}-0.001 \\
(0.05)\end{array}$ & $\begin{array}{c}0.09 * \\
(0.04)\end{array}$ \\
\hline$\Delta$ In Human capital ${ }_{t}$ & $\begin{array}{l}-28.77^{* *} \\
(10.84)\end{array}$ & $\begin{array}{l}12.55^{* * *} \\
(2.55)\end{array}$ & $\begin{array}{l}7.89 * * * \\
(2.22)\end{array}$ & $\begin{array}{l}12.89 * * * \\
(2.00)\end{array}$ \\
\hline$\Delta$ In Physical capital ${ }_{t}$ & $\begin{array}{l}0.25^{* * *} \\
(0.04)\end{array}$ & $\begin{array}{l}0.10^{* * *} \\
(0.02)\end{array}$ & $\begin{array}{l}0.17^{* * *} \\
(0.04)\end{array}$ & $\begin{array}{l}0.09 * * * \\
(0.02)\end{array}$ \\
\hline$\Delta \ln$ Institutions $_{\mathrm{t}}$ & $\begin{array}{c}0.07 \\
(0.08)\end{array}$ & $\begin{array}{c}0.14^{*} \\
(0.08)\end{array}$ & $\begin{array}{l}0.18 * * \\
(0.08)\end{array}$ & $\begin{array}{c}0.10 \\
(0.07)\end{array}$ \\
\hline$\Delta \ln$ Innovation $\mathrm{t}_{\mathrm{t}} \times \Delta \mathrm{ln}$ Institutions $\mathrm{t}_{\mathrm{t}}$ & & $\begin{array}{c}0.001^{*} \\
(0.001)\end{array}$ & & $\begin{array}{c}0.001 \\
(0.001)\end{array}$ \\
\hline \multicolumn{5}{|l|}{ Panel B: Diagnostic results } \\
\hline $\mathrm{ECT}_{\mathrm{t}-1}$ & $\begin{array}{l}-0.64 * * * \\
(0.08)\end{array}$ & $\begin{array}{l}-0.79 * * * \\
(0.07)\end{array}$ & $\begin{array}{l}-0.63 * * * \\
(0.07)\end{array}$ & $\begin{array}{l}-0.86 * * * \\
(0.05)\end{array}$ \\
\hline F-statatistic & $7.37 * * *$ & $12.86 * * *$ & $8.08 * * *$ & $31.06 * * *$ \\
\hline Adjusted $\mathrm{R}^{2}$ & 0.997 & 0.994 & 0.996 & 0.997 \\
\hline $\operatorname{LM}(2)$ & 2.34 & 3.29 & 1.01 & 0.69 \\
\hline RESET test & 0.92 & $3.22 *$ & 0.14 & 0.22 \\
\hline CUSUM (CUSUM²) & $S(S)$ & $S(S)$ & $S(S)$ & $S(S)$ \\
\hline
\end{tabular}

F-test bounds critical value for $n=30, k=5$, Case 2 (for $k=6$ )

\begin{tabular}{lccc}
\hline & $10 \%$ & $5 \%$ & $1 \%$ \\
\hline Lower bound & $2.407(2.334)$ & $2.910(2.794)$ & $4.134(3.976)$ \\
Upper bound & $3.517(3.515)$ & $4.193(4.148)$ & $5.761(5.691)$ \\
\hline
\end{tabular}

Notes: $* * *, * *$ and $*$ indicate $1 \%, 5 \%$ and $10 \%$ significant levels, respectively. The number in parentheses show the standard error for the respective coefficient. LM is the Breusch-Godfrey serial correlation test with the number of lags as stated in parentheses. RESET test is the Ramsey's reset test for misspecification of model. For CUSUM and CUSUM², S stands for stable. The models are estimated with trend if only it is significant at $10 \%$ level. F-test lower and upper bound critical values are from Narayan (2005). 
Table 5. Long-run results (linear ARDL model)

\begin{tabular}{lccccc}
\hline & \multicolumn{2}{c}{$\begin{array}{c}\text { Innovation }=\text { Total } \\
\text { patent application }\end{array}$} & & \multicolumn{2}{c}{ Innovation = Total grants } \\
\cline { 2 - 3 } \cline { 6 - 7 } & Model A & Model B & & Model C & Model D \\
\hline In Innovation & -0.09 & -0.01 & & $0.05^{* *}$ & $0.02^{* *}$ \\
& $(0.04)$ & $(0.02)$ & & $(0.02)$ & $(0.01)$ \\
In Population growth & 0.15 & 0.08 & & -0.001 & $0.10^{* *}$ \\
& $(0.09)$ & $(0.08)$ & & $(0.08)$ & $(0.04)$ \\
In Human capital & $16.70^{* * *}$ & $15.86^{* * *}$ & & $12.61^{* * *}$ & $14.93^{* * *}$ \\
& $(1.29)$ & $(0.91)$ & & $(0.93)$ & $(0.46)$ \\
In Physical capital & $0.26^{* * *}$ & $0.13^{* * *}$ & & $0.16^{* * *}$ & $0.10^{* * *}$ \\
& $(0.08)$ & $(0.03)$ & & $(0.05)$ & $(0.02)$ \\
In Institutions & $0.35^{* * *}$ & $0.18^{* *}$ & & $0.29^{* *}$ & $0.12^{*}$ \\
& $(0.09)$ & $(0.08)$ & & $(0.12)$ & $(0.07)$ \\
In Innovation $x$ In Institutions & & $0.002^{*}$ & & & $0.003^{* * *}$ \\
& & $(0.001)$ & & $(0.001)$ \\
\hline
\end{tabular}

Notes: $* * *, * *$ and $*$ indicates $1 \%, 5 \%$ and $10 \%$ significant levels, respectively. The number in parentheses shows the standard error for the respective coefficient.

more crucial than quantity innovation. The result of the study that finds a negligible contribution of innovation in Malaysia is of no surprise. It is because over the past years Malaysia has experienced a very low successful rate for both intellectual property commercialisation (Govindaraju \& Wong, 2011; Govindaraju, Abdol Ghapar, \& Pandiyan, 2008; 2009) and commercialisation of public R\&D. Asid and Khalifah (2016) supported this finding whereby they found that the initial triadic pattern only marginally improves technical efficiency. It seems that there is a "disconnect" paradox between innovation and commercialisation programs in Malaysia.

The other control variables such as physical capital stock, human capital and institutions are statistically significant determinants of economic performance in Malaysia, which is in line with the theory. For example, Baharumshah and Almasaied (2009) and Lai and Ishhak (2014) found that human capital is important for promoting Malaysian economic performance. Ang (2008), Ayub, Azman-Saini, Laila, Mongid and Wan Ismail (2019), Solarin and Shahbaz (2015) and Tang and Tan (2015) demonstrated that physical capital or investment is positively associated with economic performance in Malaysia. With respect to institutions, Bekhet and Abdul Latif (2018), Mo (2019) and Sarmidi, Law and Jafari (2014) revealed that the institutions variable is vital in promoting economic performance in Malaysia. In terms of the interaction between innovation and institutions, the finding shows that only the total patent grants variable is significant, whereas the total patent application is insignificant.

Table 6 presents the empirical results of the linear ARDL estimation and diagnostic checks for the relative importance of local and foreign innovation, which is only available for total patent application. The three models have passed the diagnostic checks especially the serial correlation and stability test. The main result is the long- 
Table 6. Linear ARDL estimation results and diagnostic checks

\begin{tabular}{|c|c|c|c|}
\hline Variable & Model A & Model B & Model C \\
\hline \multicolumn{4}{|c|}{ Panel A: Coefficient estimates of linear $A R D L$} \\
\hline Selected model & $(3,1,0,1,1,1)$ & $(1,0,0,0,0,0)$ & $(3,1,0,0,1,1,1)$ \\
\hline Constant & $-40.40(10.73)^{* * *}$ & $-39.20(11.28)^{* * *}$ & $-43.12(12.17)^{* * *}$ \\
\hline In Real GDP per capita t-1 $_{1}$ & $-0.65(0.17)^{* * *}$ & $-0.72(0.16)^{* * *}$ & $-0.66(0.18)^{* * *}$ \\
\hline In Foreign innovation $\mathrm{t}_{\mathrm{t}-1}$ & $-0.05(0.02)^{* * *}$ & & $-0.05(0.02)^{* *}$ \\
\hline In Local innovation ${ }_{\mathrm{t}-1}$ & & $0.01 \quad(0.02)$ & $-0.01 \quad(0.02)$ \\
\hline In Population growth $\mathrm{t}_{\mathrm{t}-1}$ & $0.09(0.06)$ & $0.05 \quad(0.06)$ & $0.10 \quad(0.06)$ \\
\hline In Human capital $\mathrm{t}_{\mathrm{t}-1}$ & $10.58(2.80)^{* * *}$ & $10.41(2.90)^{* * *}$ & $11.23(3.14)^{* *}$ \\
\hline In Physical capital $\mathrm{t}_{-1}$ & $0.17(0.04)^{* * *}$ & $0.10(0.02)^{* * *}$ & $0.17(0.04)^{* *}$ \\
\hline In Institutions $\mathrm{t}_{\mathrm{t}-1}$ & $0.21(0.07)^{* *}$ & $0.15(0.08)^{*}$ & $0.23(0.08)^{* *}$ \\
\hline$\Delta$ In Real GDP per capita ${ }_{\mathrm{t}-1}$ & $-0.31(0.14)^{* *}$ & & $-0.30(0.15)^{*}$ \\
\hline$\Delta$ In Real GDP per capita ${ }_{t-2}$ & $-0.25(0.12)^{*}$ & & $-0.23(0.13)^{*}$ \\
\hline$\Delta \ln$ Foreign innovation $\mathrm{t}_{\mathrm{t}}$ & $-0.01 \quad(0.02)$ & & $-0.01 \quad(0.02)$ \\
\hline$\Delta \ln$ Local innovation $_{\mathrm{t}}$ & & $0.01 \quad(0.02)$ & $-0.01 \quad(0.02)$ \\
\hline$\Delta$ In Population growth $\mathrm{t}_{\mathrm{t}}$ & $0.09 \quad(0.06)$ & $0.05 \quad(0.06)$ & $0.10 \quad(0.06)$ \\
\hline$\Delta$ In Human capital ${ }_{t}$ & $-31.71(11.06)^{* *}$ & $10.41(2.90)^{* * *}$ & $-28.93(12.53)^{* *}$ \\
\hline$\Delta$ In Physical capital ${ }_{t}$ & $0.25(0.04)^{* * *}$ & $0.10 \quad(0.02)^{* * *}$ & $0.25(0.04)^{* *}$ \\
\hline$\Delta \ln$ Institutions $\mathrm{t}_{\mathrm{t}}$ & $0.06 \quad(0.08)$ & $0.15(0.08)^{*}$ & $0.08 \quad(0.09)$ \\
\hline \multicolumn{4}{|l|}{ Panel B: Diagnostic results } \\
\hline $\mathrm{ECT}_{\mathrm{t}-1}$ & $-0.65(0.08)^{* * *}$ & $-0.72(0.07)^{* * *}$ & $-0.66(0.08)^{*}$ \\
\hline F-statstistic & $7.66 * * *$ & $13.40 * * *$ & $6.43 * * *$ \\
\hline Adjusted $\mathrm{R}^{2}$ & 0.997 & 0.994 & 0.997 \\
\hline $\operatorname{LM}(2)$ & 2.15 & 1.63 & 3.87 \\
\hline RESET test & 1.01 & $3.88^{*}$ & 0.75 \\
\hline CUSUM (CUSUM²) & $S(S)$ & $S(S)$ & $S(S)$ \\
\hline
\end{tabular}

F-test bounds critical value for $n=30, k=5$, Case 2 (for $k=6$ )

\begin{tabular}{|c|c|c|c|}
\hline & $10 \%$ & $5 \%$ & $1 \%$ \\
\hline Lower bound & $2.407(2.334)$ & $2.91 \quad(2.794)$ & 4.134 (3.976) \\
\hline Upper bound & 3.517 (3.515) & $4.193(4.148)$ & $5.761(5.691)$ \\
\hline
\end{tabular}

Notes: $* * *, * *$ and $*$ indicate $1 \%, 5 \%$ and $10 \%$ significant levels, respectively. The number in parentheses shows the standard error for the respective coefficient. LM is the Breusch-Godfrey serial correlation test with the number of lags as stated in parentheses. RESET test is the Ramsey's reset test for misspecification of model. For CUSUM and CUSUM ${ }^{2}, \mathrm{~S}$ stands for stable. The models are estimated with trend if only it is significant at $10 \%$ level. F-test lower and upper bound critical values are from Narayan (2005). 
Table 7. Long-run results (linear ARDL model) of relative importance of local and foreign innovations

\begin{tabular}{|c|c|c|c|}
\hline Variable & Model A & Model B & Model C \\
\hline In Foreign innovation & $0.078(0.03)^{* *}$ & - & $0.072(0.04)^{* *}$ \\
\hline In Local innovation & - & $0.023(0.03)$ & $-0.021(0.03)$ \\
\hline In Population growth & $0.14 \quad(0.08)$ & $0.07 \quad(0.07)$ & $0.15(0.08)^{*}$ \\
\hline In Human capital & $16.16(1.01)^{* * *}$ & $14.42(1.37)^{* * *}$ & $17.04(2.01)^{* * *}$ \\
\hline In Physical capital & $0.26(0.08)^{* * *}$ & $0.14(0.04)^{* * *}$ & $0.25(0.08)^{* * *}$ \\
\hline In Institutions & $0.33(0.08)^{* * *}$ & $0.20(0.09)^{* *}$ & $0.35(0.10)^{* * *}$ \\
\hline
\end{tabular}

Notes: $* * *, * *$ and $*$ indicate $1 \%, 5 \%$ and $10 \%$ significant levels, respectively. The number in parentheses shows the standard error for the respective coefficient.

run estimation reported in Table 7 which reveals that foreign innovation is a significant determinant of economic performance, whereas local innovation is insignificant. Again, our inclusion of both variables in the same model specification indicate that foreign innovation is significant, but not the local innovation.

Table 8 reports the quantile regression results and the finding shows that the effect of innovation (total patent grants) differs considerably, having a strong effect on economic performance at lower quantiles (10 percentile and 25 percentile). This empirical result demonstrates that the effect is much stronger at lower quantiles. Figure 3 presents the coefficient distributions of each variable; the total patent grants variable is diminishing the coefficients which is in line with the lower quantiles whereby the coefficients are significant. This result demonstrates that our innovation variable is not statistically significant as compared to literature in other developed countries (Ang, 2010; Laincz \& Peretto, 2006). The institutions variable reveal that higher quantiles level of the coefficients have higher values which are consistent with the literature, where better institutions promote economic performance. The human capital variable also reveals the same pattern.

\section{Conclusion}

Motivated by differences in innovation intensity across countries, this paper analyses an empirical investigation of the role of innovation in economic performance in Malaysia. Using the autoregressive distributed lag (ARDL) bounds test procedure, this study utilises an output per labour framework based on the notion of economic performance capacity. The time series data is from 1985 to 2016. The empirical results indicate that total patents granted that measures the quality of innovation is a statistically significant determinant of economic performance, which implies that quality innovation is more vital compared to quantity innovation. In terms of local and foreign innovations, the foreign innovation has a greater impact on economic performance. With respect to the roles of institutions in the innovation-economic growth nexus, the result reveals that institutions are crucial in accelerating the effect of innovation on economic performance. 
Table 8. Results of quantile regression

\begin{tabular}{|c|c|c|c|c|}
\hline Real GDP per capita & Coefficient & $\begin{array}{c}\text { Bootstrap } \\
\text { standard error }\end{array}$ & t-stat & p-value \\
\hline \multicolumn{5}{|l|}{ Q10 } \\
\hline Total grants & 0.0002 & $9.41 \mathrm{E}-05$ & $2.03 *$ & 0.053 \\
\hline Institutions & 0.0050 & 0.0041 & 1.22 & 0.233 \\
\hline Population growth & 0.0362 & 0.1165 & 0.31 & 0.759 \\
\hline Human capital & 14.731 & 0.7266 & $20.27 * * *$ & 0.000 \\
\hline Physical capital & 0.0984 & 0.0318 & $3.09 * * *$ & 0.005 \\
\hline Constant & -54.866 & -3.3299 & $16.48 * * *$ & 0.000 \\
\hline \multicolumn{5}{|l|}{ Q25 } \\
\hline Total grants & 0.0002 & $9.71 \mathrm{E}-05$ & $2.07 * *$ & 0.049 \\
\hline Institutions & 0.0038 & 0.0035 & 1.08 & 0.290 \\
\hline Population growth & 0.0352 & 0.1219 & 0.29 & 0.775 \\
\hline Human capital & 14.6149 & 0.7901 & $18.5^{* * *}$ & 0.000 \\
\hline Physical capital & 0.1167 & 0.0388 & $3.00 * * *$ & 0.006 \\
\hline Constant & -54.389 & -3.6071 & $15.08 * * *$ & 0.000 \\
\hline \multicolumn{5}{|l|}{$Q 50$} \\
\hline Total grants & 0.0002 & 0.0001 & 1.67 & 0.107 \\
\hline Institutions & 0.0074 & 0.0024 & $3.03 * * *$ & 0.005 \\
\hline Population growth & 0.1722 & 0.0893 & $1.93^{*}$ & 0.065 \\
\hline Human capital & 15.547 & 0.5361 & $29.00 * * *$ & 0.000 \\
\hline Physical capital & 0.1253 & 0.0219 & $5.71 * * *$ & 0.000 \\
\hline Constant & -58.645 & -2.4318 & $24.12 * * *$ & 0.000 \\
\hline \multicolumn{5}{|l|}{ Q75 } \\
\hline Total grants & 0.0001 & 0.0001 & 1.29 & 0.210 \\
\hline Institutions & 0.0078 & 0.0028 & $2.78 * * *$ & 0.010 \\
\hline Population growth & 0.0919 & 0.0984 & 0.93 & 0.359 \\
\hline Human capital & 15.018 & 0.5534 & $27.13 * * *$ & 0.000 \\
\hline Physical capital & 0.1430 & 0.0314 & $4.55 * * *$ & 0.000 \\
\hline Constant & -56.346 & -2.4678 & $22.83 * * *$ & 0.000 \\
\hline \multicolumn{5}{|l|}{ Q90 } \\
\hline Total grants & 0.0001 & 0.0002 & 0.47 & 0.641 \\
\hline Institutions & 0.0097 & 0.0046 & $2.1^{* *}$ & 0.046 \\
\hline Population growth & 0.1327 & 0.1473 & 0.9 & 0.376 \\
\hline Human capital & 15.471 & 0.8063 & $19.19 * * *$ & 0.000 \\
\hline Physical capital & 0.1075 & 0.0535 & $2.01^{*}$ & 0.055 \\
\hline Constant & -58.252 & -3.5521 & $16.4^{* * *}$ & 0.000 \\
\hline
\end{tabular}

Note: $* * * * *$ and $*$ denote significance at $1 \%, 5 \%$ and $10 \%$ levels, respectively. 


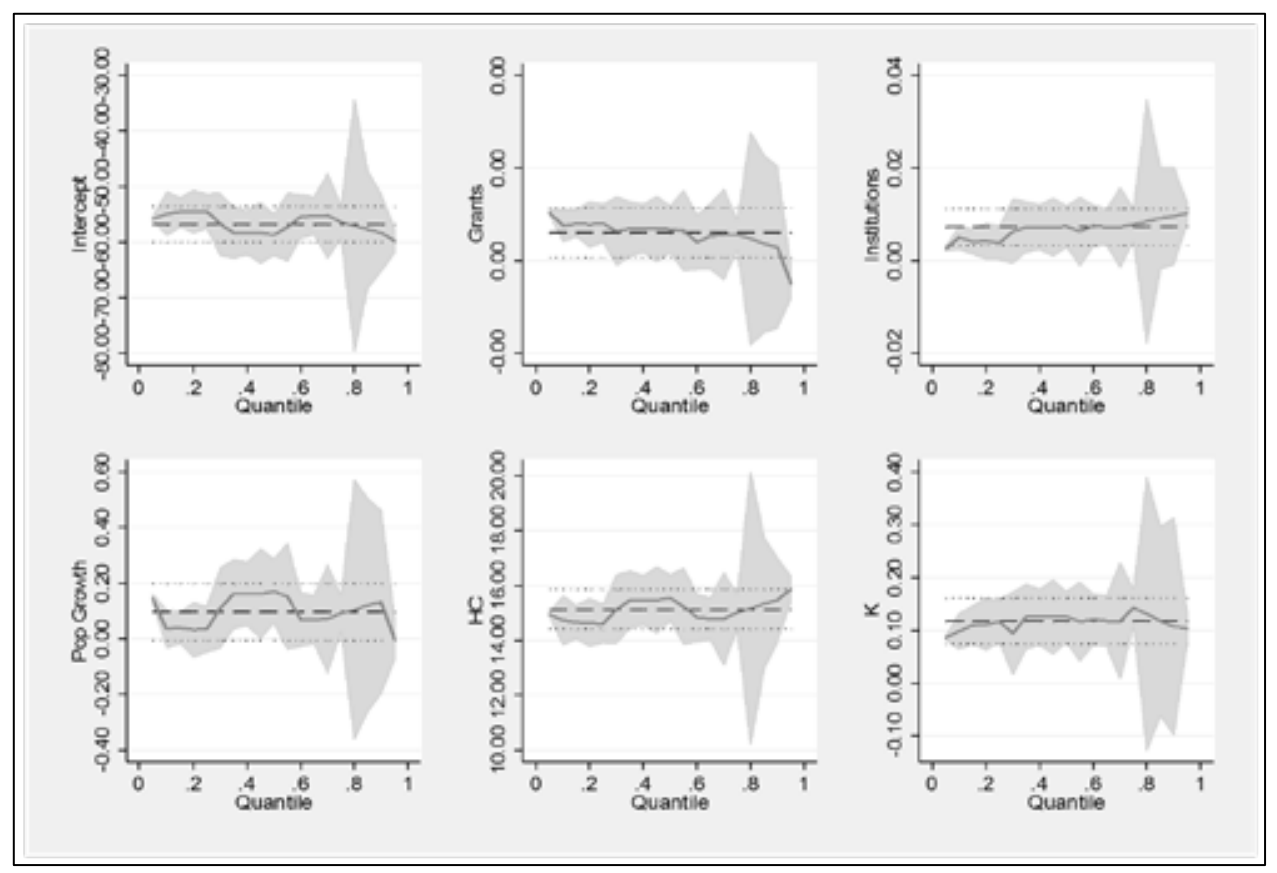

Figure 3. Quantile regression graph (the graphs show the estimates of the slope coefficients in the $x$-axis against the quantiles of economic performance in the $y$-axis)

In industry 4.0 era, technological advancement and digitisation are two important pillars for a competitive economy. Malaysia has to strategically ensure that the innovation of new technologies is adequate to drive a sustainable and inclusive economy. To achieve these aims, first, our study suggests the imperative of having new stock of novel ideas. We are producing a shallow level of innovation as compared to other countries. Second, the quality of innovation should be of prime importance. A number of new ideas alone may not significantly impact the economic performance.

The current study shows that inadequacy of innovative technology flow over the long term has a detrimental effect on innovative capacity. Premium institutional quality is of utmost priority and urgency. Our study confirms that institutional quality accelerates the innovation impact on economic performance. Any move that could shape better institutional quality including improvement of human capital, reduction in the digital literacy gap, innovation tax incentive, and higher quality of networking are vital.

\section{References}

Aghion, P., Bloom, N., Blundell, R., Griffith, R., \& Howitt, P. (2005). Competition and innovation: An inverted-U relationship. Quarterly Journal of Economics, 120(2), 701-728. https://doi.org/ https://doi.org/10.1093/qje/120.2.701

Aghion, P., \& Howitt, P. (1992). A model of growth through creative destruction. Econometrica, 60(2), 323-351. https://doi.org/10.2307/2951599 
Ang, J.B. (2008). What are the mechanisms linking financial development and economic growth in Malaysia? Economic Modelling, 25(1), 38-53. https://doi.org/10.1016/j.econmod.2007.04.006

Ang, J.B. (2010). Financial reforms, patent protection, and knowledge accumulation in India. World Development, 38(8), 1070-1081. https://doi.org/10.1016/j.worlddev.2009.12.011

Asid, R., \& Khalifah, N.A. (2016). The effects of foreign R\&D and triadic patent propensity on developing economies efficiency and convergence. Jurnal Ekonomi Malaysia, 50(2), 107-204. https://doi.org/10.17576/JEM-2016-5002-09

Ayub, M., W.N.W. Azman-Saini, Laila, N., Mongid, A. \& Wan Ismail. W.Z. (2019). Foreign direct investment and economic growth: The role of democracy. International Journal of Economics and Management, 13(2), 481-493.

Baharumshah, A.Z., \& Almasaied, S.W. (2009). Foreign direct investment and economic growth in Malaysia: Interactions with human capital and financial deepening. Emerging Markets Finance and Trade, 45(1), 90-102. https://doi.org/10.2753/REE1540-496X450106

Bekaert, G., Harvey, C.R., \& Lundblad, C.T. (2005). Does financial liberalization spur growth? Journal of Financial Economics, 77(1), 3-55. https://doi.org/10.1016/j.jineco.2004.05.007

Bekaert, G., Harvey, C.R., \& Lundblad, C.T. (2006). Growth volatility and financial liberalization. Journal of International Money and Finance, 25(3), 370-403. https://doi.org/10.1016/j. jimonfin.2006.01.003

Bekhet, H.A., \& Abdul Latif, N.W. (2018). The impact of technological innovation and governance institution quality on Malaysia's sustainable growth: Evidence from a dynamic relationship. Technology in Society, 54(August), 27-40. https://doi.org/10.1016/j.techsoc.2018.01.014

Cameron, G. (1998). Innovation and growth: A survey of empirical evidence (Working paper). Oxford, UK: Nuffield College.

Chong, A., \& Calderón, C. (2000). Institutional quality and income distribution. Economic Development and Cultural Change, 48(4), 761-786. https://doi.org/10.1086/452476

Demetriades, P., \& Law, S.H. (2006). Finance, institutions and economic development. International Journal of Finance \& Economics, 11(3), 245-260. https://doi.org/10.1002/ijfe.296

Eichengreen, B., Park, D., \& Shin, K. (2013). Growth slowdowns redux: New evidence on the middle-income trap (NBER Working Paper No. 18673). Cambridge, MA: National Bureau of Economic Research. https://doi.org/10.3386/w18673

Galindo, M.Á., \& Méndez, M.T. (2014). Entrepreneurship, economic growth, and innovation: Are feedback effects at work? Journal of Business Research, 67(5), 825-829. https://doi. org/10.1016/j.jbusres.2013.11.052

Gill, I., \& Kharas, H. (2007). An East Asian renaissance: Ideas for economic growth. Washington, DC: World Bank.

Govindaraju, V.G.R. Chandran, \& Wong C.Y. (2011). Patenting activities by developing countries: The case of Malaysia. World Patent Information, 33(1), 51-57. https://doi.org/10.1016/j. wpi.2010.01.001

Govindaraju, V.G.R. Chandran, Abdol Ghapar, F., \& Pandiyan, V. (2008). The commercialization of research results among researchers in public universities and research institutions. Asian Profile, 36(3), 235-250.

Govindaraju, V.G.R. Chandran, Abdol Ghapar, F., \& Pandiyan, V. (2009). The role of collaboration, market and intellectual property rights awareness in university technology commercialization. International Journal of Innovation and Technology Management, 6(4), 363-378. https://doi.org/10.1142/S0219877009001674

Grossman, G.M., \& Helpman, E. (1991). Innovation and growth in the global economy. Cambridge, MA: MIT Press.

Guloglu, B., \& Tekin, R.B. (2012). A panel causality analysis of the relationship among research and development, innovation, and economic growth in high-income OECD countries. Eurasian Economic Review, 2(1), 32-47. https://doi.org/10.14208/BF03353831 
Hasan, I., \& Tucci, C.L. (2010). The innovation-economic growth nexus: Global evidence. Research Policy, 39(10), 1264-1276. https://doi.org/10.1016/j.respol.2010.07.005

Hall, R.E., \& Jones, C.I. (1999). Why do some countries produce so much more output per worker than others? Quarterly Journal of Economics, 114(1), 83-116. https://doi.org/10.3386/w6564

Jalles, T.J. (2010). How to measure innovation? New evidence of the technology growth linkage. Research in Economics, 64(2), 81-96. https://doi.org/10.1016/j.rie.2009.10.007

Knack, S., \& Keefer, P. (1995). Institutions and economic performance: Cross-country tests using alternative institutional measures. Economics \& Politics, 7(3), 207-227. https://doi. org/10.1111/j.1468-0343.1995.tb00111.x

Knight, M.D., Loayza, N., \& Villanueva, D. (1993). Testing the neoclassical theory of economic growth: A panel data approach. IMF Staff Papers, 40(3), 512-541. https://doi. org/10.2307/3867446

Koenker, R. (2005). Quantile regression. Cambridge, UK: Cambridge University Press. https://doi. org/10.1017/СВO9780511754098

Koenker, R., \& Bassett, G. (1978). Regression quantiles. Econometrica, 46(1), 33-50. https://doi. org $/ 10.2307 / 1913643$

Lai, W.S., \& Ishak, Y. (2014). Human capital accumulation and economic growth in Malaysia Investigating the long-run nexus. Jurnal Ekonomi Malaysia, 48(1), 155-165. https://doi. org/10.17576/JEM-2014-4801-13

Laincz, C., \& Peretto, P. (2006). Scale effects in endogenous growth theory: An error of aggregation, not specification. Journal of Economic Growth, 11(3), 263-288. https://doi. org/10.1007/s10887-006-9004-9

Law, S.H., \& Azman-Saini, W.N.W. (2012). Institutional quality, governance and financial development. Economics of Governance, 13(3), 217-236. https://doi.org/10.1007/s10101-012-0112-z

Law, S.H., \& Azman-Saini, W.N.W. (2013). Capital account liberalization and economic performance in Malaysia. Singapore Economic Review, 58(3). https://doi.org/10.1142/ S0217590813500227

Lee, K., \& Kim, B. (2009). Both institutions and policies matter but differently for different income groups of countries: Determinants of long-run economic growth revisited. World Development, 37(3), 533-549. https://doi.org/10.1016/j.worlddev.2008.07.004

Mankiw, N.G., Romer, D., \& Weil, D.N. (1992). A contribution to the empirics of economic growth. Quarterly Journal of Economics, 107(2), 407-437. https://doi.org/10.2307/2118477

Mo, P.H. (2019). Institutions' complementarity and coevolution. Malaysian Journal of Economic Studies, 55(1), 133-150. https://doi.org/10.22452/MJES.vol55no1.8

Mc Morrow, K., \& Röger, W. (2009). R\&D capital and economic growth: The empirical evidence. EIB Papers, 4(1), 94-118.

Narayan, P.K. (2005). The saving and investment nexus for China: Evidence from cointegration tests. Applied Economics, 37(17), 1979-1990. https://doi.org/10.1080/00036840500278103

Pece, A.M., Simona, O.E.O., \& Salisteanu, F. (2015). Innovation and economic growth: An empirical analysis for CEE countries. Procedia Economics and Finance, 26, 461-467. https://doi. org/10.1016/S2212-5671(15)00874-6

Pesaran, M.H., Shin, Y., \& Smith, R.J. (2001). Bounds testing approaches to the analysis of level relationships. Journal of Applied Econometrics, 16(3), 289-326. https://doi.org/10.1002/ jae.616

Pradhan, R.P., Arvin, M.B., \& Bahmani, S. (2018). Are innovation and financial development causative factors in economic growth? Evidence from a panel granger causality test. Technological Forecasting \& Social Change, 132(C), 130-142. https://doi.org/10.1016/j. techfore.2018.01.024

Romer, P.M. (1986). Increasing returns and long-run growth. Journal of Political Economy, 94(5), 1002-1037. https://doi.org/10.1086/261420 
Romer, P.M. (1990). Endogenous technological change. Journal of Political Economy, 98(5), S71-S102. https://doi.org/10.1086/261725

Sarmidi, T., Law, S.H., \& Jafari, Y. (2014). Resource curse: New evidence on the role of institutions. International Economic Journal, 28(1), 191-206. https://doi.org/10.1080/10168737.2013.787 110

Schumpeter, J.A. (1939). Business cycles: A theoretical, historical and satistical analysis of the capitalist process. New York, NY: McGraw-Hill.

Schneider, F. (2005). Shadow economies around the world: What do we really know? European Journal of Political Economy, 21(3), 598-642. https://doi.org/10.1016/j.ejpoleco.2004.10.002

Solarin, S.A., \& Shahbaz, M. (2015). Natural gas consumption and economic growth: The role of foreign direct investment, capital formation and trade openness in Malaysia. Renewable and Sustainable Energy Reviews, 42(February), 835-845. https://doi.org/10.1016/j. rser.2014.10.075

Tan, B.-Y., \& Azman-Saini, W.N.W. (2017). Foreign direct investment and research \& development activity: The role of competition. International Journal of Economics and Management, 11(2), 467-482.

Tang, C.F., \& Tan, E.C. (2015). Does tourism effectively stimulate Malaysia's economic growth? Tourism Management, 46(February), 158-163. https://doi.org/10.1016/j.tourman.2014.06.020

Wu, J., Zhuo, S., \& Wu, Z. (2017). National innovation system, social entrepreneurship, and rural economic growth in China. Technological Forecasting and Social Change, 121(August), 238250. https://doi.org/10.1016/j.techfore.2016.10.014

Yang, C.-H. (2006). Is innovation the story of Taiwan's economic growth? Journal of Asian Economics, 17(5), 867-878. https://doi.org/10.1016/j.asieco.2006.08.007 